\title{
Using Communities of Practice for the Learning of Students with Poor Vision
}

\author{
http://dx.doi.org/10.3991/ijac.v5i3.2197 \\ Tatiana Takimoto, Gertrudes Aparecida Dandolini, João Artur Souza and Tarcísio Vanzin \\ Federal University of Santa Catarina, Florianopolis, Brazil
}

\begin{abstract}
The Graduate Program in Engineering and Knowledge Management, at Federal University of Santa Catarina, with the support from CAPES PROESP, developed a project which focus is the development of an adaptable and accessible web environment for teaching the discipline of Descriptive Geometry - WebGD. This article presents the parameters needed for social and educational inclusion of students with vision impairment and it is based on a strategy to encourage participation and interaction on communities of practice. A review of literature on distance education, situated cognition and Communities of Practice was held, concepts that support the project WebGD, and a literature review of low vision - vision impairment. At the end requirements needed to develop the next steps for the WebGD project are presented.
\end{abstract}

Index Terms-communities of practice, information and communication technologies, distance education, low vision/vision impairment

\section{INTRODUCTION}

The growth of the Internet and the evolution of information and communication technology contributed to a considerable increase in distance education courses because of the break of the time and space barrier, overcoming problems of physical distance and available time. According to data from INEP, 2008, 115 institutions offered 647 distance learning courses in Brazil. Enrollment for distance teaching increased $96.9 \%$ over the previous year and in 2008 became $14.3 \%$ of total enrollment in college education. In addition, the number of 2 graduates in distance education has grown to $135 \%$ in 2008 compared to 2007. However the information is not available on how many graduating students have some deficiency, either visual, hearing or motor. The social and educational inclusion of students with disabilities demands the realization of projects and research that makes it viable and effective, said [14].

The Graduate Program in Engineering and Knowledge Management, at the Federal University of Santa Catarina, with support from CAPES PROESP, developed a project which focus is the development of a web environment adaptable and accessible to the Descriptive Geometry teaching from the perspective of inclusive education. The objective of this article is to identify the needs of the user with low vision in parameters recommended by the authors [3], [8], [15] and [22] and compare them with the communities of practice guidelines proposed by [28]. The researches of these requirements are necessary for the continuation of the WebGD project including students with low vision.

A literature review on Distance Education, situated cognition, and Communities of Practice was done, as these concepts justify and support the WebGD project objective. The difficulties of students with low vision reported here, will work as a basis for the continuity of the WebGD project and facilitate the development of inclusion strategies for these students in distance education courses, giving them comfort and to encourage their interaction with the rest of the class and therefore their learning.

\section{THE WEBgD PROJECT}

The project goal is to develop a WebGD web environment adaptable and accessible for the teaching of Descriptive Geometry on the point of view of inclusive education. The course will be implemented in the Moodle virtual learning environment for its pedagogical principle back to the "social constructivism", range and high interactivity. The audience that will attend this course will be to young students with or without disabilities and hearing impairment and /or visual disability, attending college or technical courses of engineering, mathematics, design, art or other area that uses this discipline or an equivalent course in their curriculum.

The Geometry course aims to improve the spatial vision of these students, teaching them to represent a threedimensional object on a two-dimensional surface. One of the results of this project is doctoral thesis of [12] which deals with guidelines for creating accessible learning objects. This thesis will support the creation of adaptable and accessible objects learning that will be available on the AVA project. Ref. [1] works on the inclusion of accessibility guidelines in a Adaptive Hypermedia System provided information for the development of graphical user interface.

Some precautions have been taken in developing this interface: the software programming is consistent with the recommendations of the World Wide Web Consortion (W3C) guidelines and with the Web Content Accessibility Guidelines (WCAG), so that the interface is already accessible to users who are blind and deaf, as shown in Figure 1 . The project is still in its early stages, and in order to be continued, this paper investigates the real needs of students with low vision. 


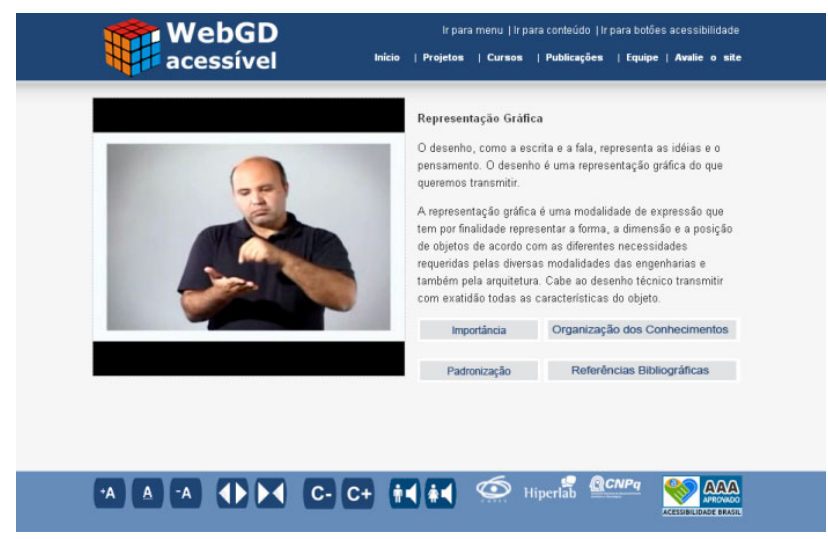

Figure 1. Screen shot of WebGD website

\section{DisTANCE EDUCATION}

To [6], distance education (DE) is a teaching and learning form in which teachers and students are separated geographically. According to Oliveira [18], the distance education students are empowered to conduct researches about the content that interests them, and to take an active and responsible attitude about their own learning. The combination of autonomy with the ease of students in finding information and consequently produce knowledge causes teachers to change their conduct. In this scenario we can say that among the changes occurred in distance education during the XX and XXI centuries, the most revolutionary one is in the field of communication through internet media.

According to [2], the same information and communication technologies (ICT) to enhance the process of globalization are used by DE. Therefore, ICTs have become essential in the teaching and distance learning, no longer an option and becoming a mark of this subject. So, the DL must adapt to new technologies and insert them into the education day-to-day, exploiting resources such as hypermedia and interactive communication networks.

Communication in Distance Education occurs among students, tutors and teachers in virtual learning environments, which generally seeks similar features like the physical classroom, with special interest in interactivity. The access to files related to the content is highly facilitated and the feeling of isolation characteristic of older forms of distance education - don't exist anymore because of the indications of other group member presence, the fast communication software and the communication resources with online voice and image.

\section{VIRTUAL LEARNING ENVIRONMENT}

The concept of virtual learning environment (VLE) is "media option that is being used to mediate the process of teaching-learning" said [23]. Ref. [11] adds that VLEs are increasing in the academic community, both in private and public teaching institutions and also in some organizations linked some way to the teaching process. Besides being widely used in distance courses they are also being explored by teachers inside of physical classrooms.

The Moodle (Modular Object-Oriented Dynamic Learning Environment), free software developed by australian Martin Dougiamas is an AVA example which is being used by 54,442 sites registered in 212 countries. There are 3863 institutions in Brazil that use Moodle, according to statistics from Moodle community site [17]. This number indicates the need for studies in the area so the for the AVAs can be effective in their goal, which is to provide a resources management environment to accelerate the availability and exchange of files and facilitate the integration among the participants, all in order to promote learning.

Although the advancement of ICT enables the emergence of new forms of communication, interaction and collaboration, [11] highlights the fact that the VLEs are often used as mere repositories and distribution tools of instructional materials, and end up not using all the potential that ICTs have to offer. [7] supports [11] and asserts that even the television and computer technologies considered most widely used in education communication, has not led to radical changes in the structure of the courses.

The behavior change of those involved in the process of teaching and learning is being discussed in several aspects. Ref. [27] states that the pedagogical debates are conducted with a focus on options as authority versus freedom, instruction versus discovery, individual versus collective. The author emphasizes that all these direct discussions on the issue suggests that interactivity and VLEs should prioritize the collective learning, using ICT for collaboration and cooperation among students, tutors and teachers.

Ref. [21] studies about that online education state that the students enrolled in distance education, especially the younger ones, have a larger facility with ICT when compared to their own teachers. These students often use the communication technologies for social networking. In this context, the authors say that teachers should encourage the sense of community among students, which refers to the concept of communities of practice, developed by researcher [27].

\section{COMmunities OF PRACTice}

The authors in [10] were pioneers in the formulation of the situated cognition theory which focus is the relationship between learning and the society situation in which it occurs. According to the researchers, learning is a social dimension, acquired by experience, by participation and collaboration in everyday life. To [20], the social aspect of learning is the most important factor in the acquisition of knowledge. As a consequence of this concept of community of practice gains importance in the same pace that its members develop a sense of confidence and begin to share information and experiences.

The term community of practice (CoP) was developed by [27] to name the groups of people who interact, learn together, build personal relationships and develop a sense of belonging and commitment with each other. When entering the online environment, communities of practice become considered, according to [25], virtual communities. The virtual community of practice serves as a hypermedia platform for exchanging and storing files, whether this files are images, sounds, videos or texts. Moreover, with the strong potential for internet communication, these communities go beyond the boundaries of countries and organizations, with no age limit determined, with profit or not, resulting in a very wide participation. More than virtual meetings, a virtual community values the creation and exchange of ideas, an 
approach to support its members, resulting in a mutual and effective collaboration.

Reference [20] indicates a growing appreciation of communities in VLEs. These study results provide support for the understanding that the key for the success of online learning is the effective formation of virtual communities. Ref. [20] describes some positive changes, for example, greater access to information and greater involvement of teachers and students, increasing responsibility both in teaching and learning. Thus we can say that the success of online learning depends more on methodology than the AVA and ICT. This methodology should encourage interactivity and participation among agents in the process. Students need to contribute to collective learning, expressing their ideas in online discussions. With that, students and teachers participate of the process of acquiring knowledge collaboratively.

Reference [24] presented a methodology proposition for distance learning based on studies of how to encourage participation in a community of practice carried out by [13] and [5]. The proposal of [24] involves:

Step 1: identifying barriers to participation;

Step 2: identification of incentives for participation;

Step 3: Develop a participation strategy considering the social and cultural behavior of the group, the difficulties of participation, the motivating factors of involvement, the participation of minorities and the creation of incentives and rewards.

Step 4: Implementation of the strategy of participation.

Step 5: Evaluation of the participation strategy adopted and the gain of knowledge insights about the entire process, and at the end of this stage go back to the starting point correcting problems found during the evaluation.

The methodology presented suggests an educators' behavioral change. They need to hear what was not said. According to the authors, there is a need for "greater attention" from educators, to identify the difficulties that prevent a real interaction. These difficulties are exacerbated when there are students with some degree of disability, that could be a hearing or even, motor or visual disability. In this case teachers and tutors should pay special attention to the item "participation of minorities," which is related to step 3 of [24] methodology.

\section{VISION IMPAIRMENT - STUDENTS WITH LOW VISION}

According to [3], in 1992, the World Health Organization (WHO) defined a person with low vision as someone "who has the same visual impairment after treatment and /or standard refractive correction." This person, however, is able to use the vision or plan to perform tasks.

Following [8] the visual impaired person with low vision is the one who presents problems such as dimming of vision; blurry vision, fog, film in the eyes, vision of only extremely close objects extremely with loss of distant vision, distorted vision, spots in front of the vision; distortion of colors or color blindness, visual field defects, tunnel vision, lack of peripheral vision, abnormal sensitivity to light or glare, night blindness. In addition to the mentioned data, the Human Resources Training Program in elementary schools [4] points to the fact that each student with low vision is unique and each one can present a different difficulty. While for some students is necessary to use high enlightenment to others, shimmer and shine can make a harder setting and visual discrimination. Figures 2, 3 and 4 show examples of low vision's causes.

Thus, the role of educators is to objectify the enrichment of knowledge eliminating such significant visual barriers. Here the standardization is not a good option because of the graphical elements of the AVA must be adapted to the needs of each student.

Some students have increasing visual difficulties, which often lead to sharpen senses like touch and hearing. In this scenario the authors [15] consider the use of the ICTs of fundamental importance for social and professional development of students.

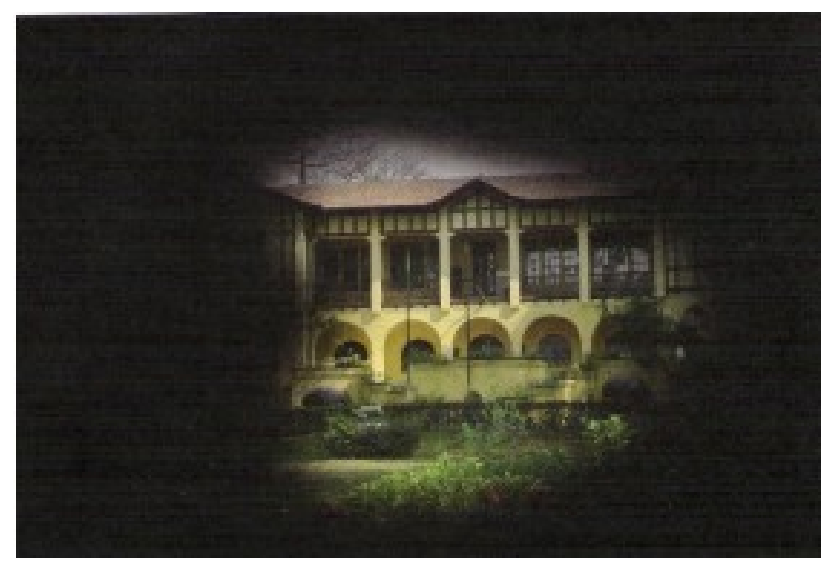

Figure 2. Glaucoma [8]

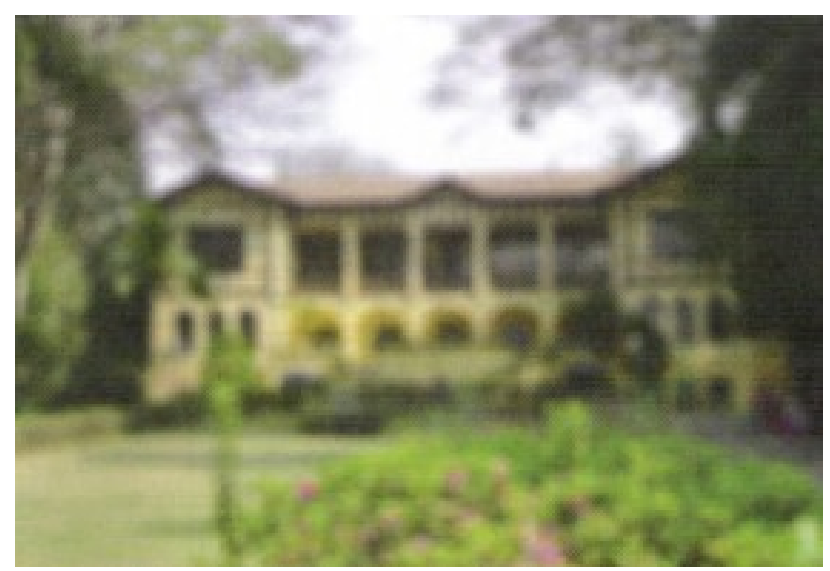

Figure 3. Cataract [8]

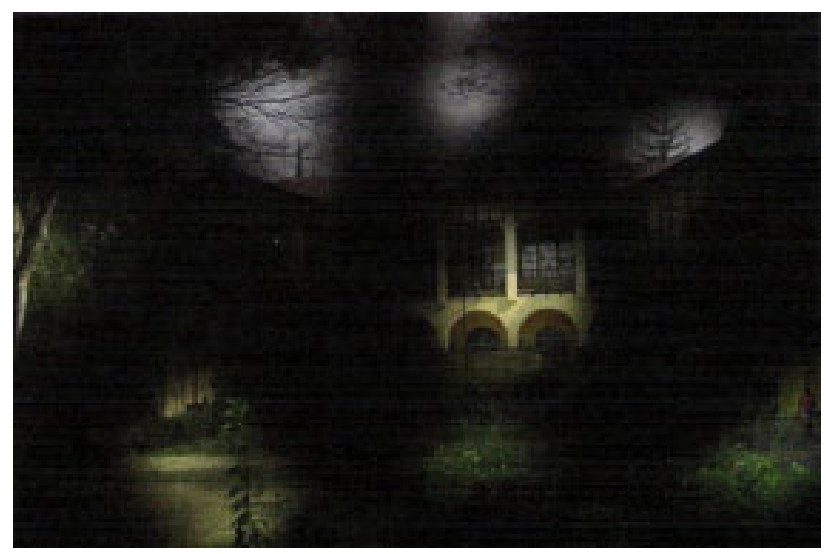

Figure 4. Diabetic Retinopathy [8] 
The ICTs associated with an appropriated pedagogy, which aims the social integration of the student, will allow the student of low vision to use their touch, hearing and visual residues efficiently in all activities, ensuring the organization of their knowledge and a greater degree of freedom and autonomy.

The policy of social integration - the basic concept of communities of practice - facilitates the breakdown of social prejudice, considered one of the most significant barriers for the students that are visually impaired, said [22]. Therefore, educators must develop its strategic participation, considering the social behavior of the group and students with low vision. In addition, teachers and guardians should eliminate barriers for the participation and encourage the promotion of interaction and collaboration, including the disabled student.

From this perspective, the development of the project WebGD, with support of PROESP CAPES, uses the methodology of [24] and relies on the theories about Cognition and Communities of Practice.

\section{REMOVING BARRIERS IN THE WEBGD PROJECT}

In the case of WebGD project, which is still being implemented, ways to develop educational materials, as objects of accessible learning [19] and structure of the virtual environment (Moodle) have been explored to facilitate the creation of communities of practice involving both students with hearing or visual disabilities and those without.

Below, we present some recommendations focused on breaking down the barriers for the students with low vision concerning their knowledge access. These recommendations are being analyzed and applied WebGD in the project. The recommendations found in [15] and [8] for students with low vision are as follows: Avoid cursive fonts, decorative, serifs and italics; Use font styles which its letters occupy a fixed space and dimension or those where space is proportional to the letter; Use bold type but not the extra-bold and avoid underlined; justify only the left margin of the text; In the images, eliminate unnecessary details; The content of the page must contain a minimum of information; The content of the interface should be organized in a well-defined column; Indication of the main menu featured in high contrast, the main menu should be on the left side of the page; Screen magnification without quality loss of quality; The interface should not contain moving images; The space should be larger "between-letter" when it is enlarged; The color of the background should change when the cursor passes through a link, using high contrast between the background and text; Use few colors on the same page. The Papo-Mania software, figure 5, is an example of interface for low vision people.

Reference [8] has tested nine color choices among users with low vision. The authors state that contrary to what many collaborators believed, the contrast of black background with yellow letters brought no apparent benefits to the reading and understanding the interface for most users. The dark blue background with white letters, bright yellow, light blue or light orange light was the contrast that allowed the best performance of navigation on the interface and proved to be the most efficient for reading as well. An example is shown in figure 6. The black background, with white, light blue, light yellow or

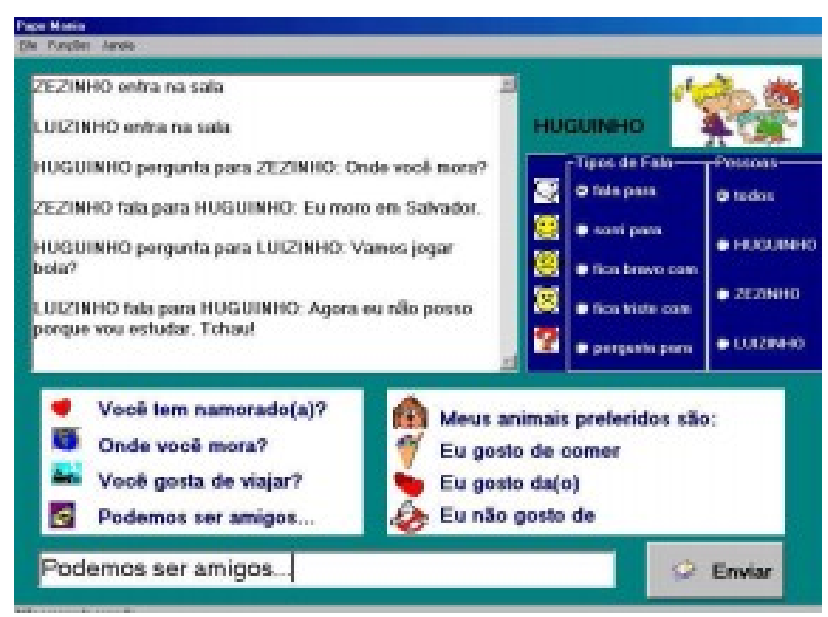

Figure 5. Papo-Mania software [8]

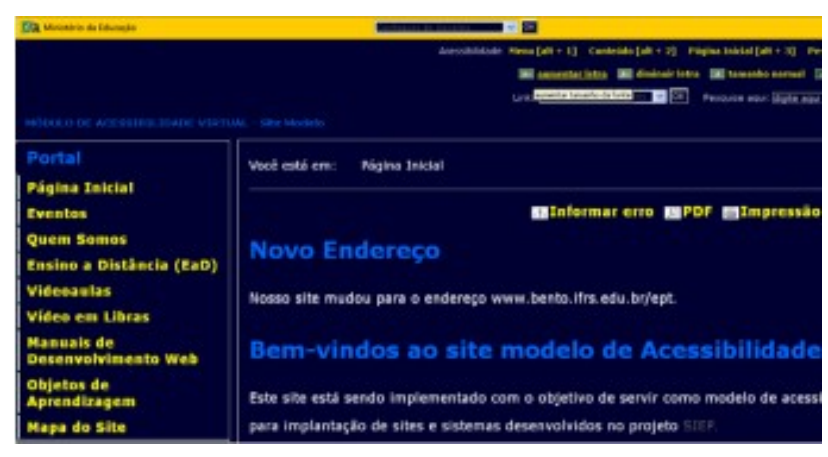

Figure 6. Website with dark blue background [8]

green light lettering, reached different types of diagnosis of low vision.

Other color combinations are recommended by the authors for assistance in identifying icons, titles and topics. Ref. [8] also have combinations of contrasts for users with and without sensitivity to light. The studies of [8] will provide a basis for implementations to be made to the interface of the WebGD project.

To facilitate student learning, the WebGD project takes as its principle the theory of situated cognition which deals with social and collaborative learning, where interactivity is an integral part of the educational process. According to [20], the key to the learning process is the interaction among students themselves, interaction among students, tutors and teachers resulting from this interaction and collaboration. For [26], situated learning is based on two principles: 1) Knowledge needs to be presented and learned in an authentic context, with the natural elements and applications that involve that knowledge 2) Learning requires social interaction and collaboration.

Because of these two principles, the Descriptive Geometry course predicts the contextualization of the students, which will allow them to apply what was learned. According to [26] "cognitive activities resulting from the learning process can be only explained as they relate to the context."This requires that educators know their students and the context of their social life, even in distance education. In this sense, [20] claim that to mediate online learning, educators need to know the needs of students. In regards of the WebGD project, this knowledge is through education and literature researches, as well as qualitative research, face to face with people who have visual and hearing difficulties. These studies 
provide a basis for information that will fit the graphical interface of the virtual environment of digital learning and learning objects in it that will be available.

\section{FINAL CONSIDERATIONS}

While advances in computer science point to a growing demand from distance learning courses, ICTs are not used effectively in this context, especially those that provide interactivity. It is necessary a methodology change that provides social interaction among students and thus makes possible the exchange of experiences, information and knowledge among them. To motivate the participation and ensure student learning, whether disabled or not, the WebGD project is structured on the concepts of situated cognition [10] and communities of practice [28].

This paper presents a methodology [24], based on motivational strategies of communities of practice, being applied in the WebGD project development. One of the steps of the methodology is the minority inclusion, represented here by students with low vision. As one of the steps [24] methodology, predicts the elimination of the barriers to participation, it became necessary to study the people with vision impairment - low vision. This article presented a summary of the barriers faced by these students and some graphic solutions to eliminate them.

The next steps of this project include the implementation and adequation of the interface with the requirements gathered here, testing the interface with students with low-vision, creating learning objects accessible for the set of the 12 modules of the subject and development of a collaborative virtual environment to exchange information, knowledge and experience between students and teachers. It is believed that the interdisciplinary approach in the development of the WebGD project promotes a good performance and learning of the students and as well their teachers.

\section{REFERENCES}

[1] A.M. Amaral, R. CECÍLIO, V.R. Ulbricht, C.H. Berg, I, G. Dandolini, D. Kaminski, "Websites acessíveis e o uso de CMS". In: Cadernos de Informática, 6, 1, 2011, Anais do VI Congresso Ibero-americano de Telemática, 2011. CITA. Gramado, RS. p. 187-194.

[2] M. L. Belloni, Educação a distância. Campinas, SP: Autores Associados, 2008. 124p.

[3] F.A.S. Bonatti, Desenvolvimento de equipamento de auxílio à visão subnormal. Arquivos Brasileiros de Oftalmologia, v.69, n.2,p.221-226, 2006. $\quad$ http://dx.doi.org/10.1590/S000427492006000200016

[4] BRASIL. Programa de Capacitação de Recursos Humanos do Ensino Fundamental: deficiência visual. Brasília: Ministério da Educação, Secretaria de Educação Especial, 2001. v.2.

[5] D. Keegan, Foundations of distance education. New York: RoutledgeFalmer, 1996. 240 p.

[6] V. M. Kenski, Educação e Tecnologias: o novo ritmo da informação. Campinas, SP: Papirus, 2007.

[7] C.C. Kulpa, F. G. Teixeira, R.P. Silva, "Um modelo de cores na usabilidade das interfaces computacionais para s deficientes de baixa visão”. Design \& Tecnologia - Revista do programa de pósgraduação em Design da UFRGS, Porto Alegre: v.1, n.1., p.66-78, 20109

[8] J. Lave, Cognition in Practice: Mind, mathematics and culture in everyday life. New York.Cambridge University Press, 1988. 214 p. http://dx.doi.org/10.1017/CBO9780511609268
[9] J. Lave, E. Wenger, Situated Learning: Legitimate Peripheral Participation. Cambridge: Cambridge University Press, 1991. 138 p. http://dx.doi.org/10.1017/CBO9780511815355

[10] P.S.R. Lima, Um Ambiente Colaborativo de Aprendizagem Interdisciplinar Apoiado por Interfaces Adaptativas, no Estado do Pará, Belém: UFPA / CT / PPGEE, 2007. 259 p. Tese de Doutorado.

[11] C.M.S. Macedo, Diretrizes para criação de objetos de aprendizagem acessíveis, no Estado de Santa Catarina. Florianópolis: UFSC/EGC, 2010, 271 p. Tese de Doutorado.

[12] A.M. Melo, M.C.C. Baranauskas, F.F.G. Bonilha, “Avaliação de acessibilidade na Web com a participação do usuário: um estudo de caso". In: Simpósio Sobre Fatores Humanos Em Sistemas Computacionais, 6., 2004, Curitiba, Anais do VI Simpósio sobre Fatores Humanos em Sistema, 2004. SBC. Porto Alegre, RS. pp. 165-168

[13] A. Mendonça, C. Miguel, G. Neves, M. Micaelo, V. Reino, Alunos cegos e com baixa visão: orientações curriculares. Lisboa: Direcção-Geral de Inovação e de Desenvolvimento Curricular, 2008. 87 p.

[14] D.M. Monteiro, V.M.B. Ribeiro, M. STRUCHINER, “As tecnologias da informação e da comunicação nas práticas educativas: espaços de interação? Estudo de um fórum virtual.” Educação e Sociedade - Revista de ciência da educação,Campinas, v.28, n.101, p 1435 - 1454, set./dez. 2007.

[15] MOODLE. Free software livre. Developed by 279 programmers. Presents app. for the teachers use when creating websites focusing learning. Available in: http://moodle.org/sites/. Access on: May 27th, 2011.

[16] E.G. Oliveira, Educação a distância na transição paradigmática. São Paulo: Papirus, 2006. 144 p.

[17] A. V. Nunes, R. Busarello, G. A. Dandolini, G. A. Souza, V. Ulbricht, T. Vanzin, "Construção de objetos de aprendizagem acessível: foco na aprendizagem significativa”. In: Cadernos De Informática, 6, 1, 2011, Anais do VI Congresso Ibero-americano de Telemática, 2011. CITA. Gramado, RS. p. 245-248.

[18] R. M. Palloff, K. Pratt, Building online learning communities: effective strategies for the online classroom, San Francisco, CA: Jossey-Bass Publishers, 2007. 292 p.10

[19] R. M. Palloff, K. Pratt, Assessing the online learner: resources and strategies for faculty. San Francisco, CA: Jossey-Bass Publishers, 2008. 153 p.

[20] ,J.L.C Pereira, M.P.T. Costa, “O aluno com deficiência visual em sala de aula: informações gerais para professores de artes”. Revista Eletrônica de Educação. São Carlos, SP: UFSCar, v.3, n.1.p.8999, mai.2009

[21] A.T.C. Pereira, V. Schmitt, M.R.A.C. Dias, “Ambientes virtuais de aprendizagem”. In: Pereira, A.T.C. (Org.). Ambientes Virtuais de Aprendizagem em Diferentes Contextos. Rio de Janeiro: Ciência Moderna, 2007. p.4-22.

[22] T. Takimoto, M.M. Braga, C. Schons; R.K. Grando, A.T.C. Pereira, "Um modelo para educação a distância baseado nas estratégias de motivação das comunidades de prática”. In: $9^{\circ}$ Congresso Brasileiro de Gestão do Conhecimento, 2010, Gramado. Anais. São Paulo: Sociedade Brasileira de Gestão do Conhecimento. 2010. (CD-ROM).

[23] J. C.C Terra, C. Gordon, Portais Colaborativos: A revolução na gestão do conhecimento.São Paulo: Elsevier 2002. 453 p.

[24] T. Vanzin, TEHCo - Modelo de ambientes hipermídia com tratamento de erros, apoiado na teoria da cognição situada, no Estado de Santa Catarina. Florianópolis: UFSC/PPGEP, 2005, 188 p. Doctor Degree Thesis.

[25] E. Wenger, Communities of practice: learning, meaning, and identity. Cambridge: Cambridge University press, 1999. 318p.

[26] E. Wenger, Communities of Practice. Learning as a social system. The Systems Thinker, Vol. 9, No. 5, June/July 1998 Disponível: http://www.co-il.com/coil/knowledge-garden/cop/lss.shtml Acessado em: 16/05/2011

[27] E. Wenger, R. McDermott, W. Snyder, Cultivating communities of practice: a guide to managing knowledge. Boston: Harvard Business School Press, 2002. 284 p. 


\section{AUTHORS}

T. Takimoto is with the Federal University of Santa Catarina, Department of Knowledge Engineering, Florianopolis - SC, 88040-970, Brazil (e-mail: tatiana@egc.ufsc.br)

G. A. Dandolini is with the Federal University of Santa Catarina, Department of Knowledge Engineering, Florianopolis - SC, 88040-970, Brazil (e-mail: gtude@egc.ufsc.br)

J. A. Souza is with the Federal University of Santa Catarina, Department of Knowledge Engineering,
Florianopolis - SC, 88040-970, Brazil (e-mail: jartur@egc.ufsc.br).

T. Vanzin is with the Federal University of Santa Catarina, Department of Knowledge Engineering, Florianopolis - SC, 88040-970, Brazil (e-mail: tvanzin @egc.ufsc.br).

This article is an extended version of a paper presented at the conference ICELW2012, held June 2012, at Columbia University, in New York, NY, USA. This work has been done with the support of CAPES, a Brazilian Government entity focused on the formation of human resources. Manuscript received 20 July 2012. Published as resubmitted by the authors 05 August 2012. 